\title{
An Excursion on Linnaeus's Drum from Sorsele
}

\author{
BY BO LUNDMARK
}

Iter lapponicum anno 1732

\section{June 2nd}

"All this land of the Lapps was mostly bog, hinc vocavi Styx The priest can never describe hell, but that this is worse Never have the poets been able to portray Styx so vilely, so this is not viler We went forth into the wilderness, without knowing where a bog (Lycksmyren, since a stream runs from here to Lycksele, cur non Olycksmyren?) full of ochre and wate: with a coating on it

June 3rd

"We waited long into the day towards 2 o'clock in the afternoon for the Lapp we had sent, who finally returned quite exhausted, having sought so many habitations in vain. With him came a person, I knew not if it were man or woman; I do not think that poet ever portrayed a fury that was not better presented by this person, who, not without reason, one must believe was come from Styx She looked quite small, her face was quite blackened by smoke, her eyes were brown and shming, her eyebrows black, her hair as black as ink and matted on her head I was afraid at first sight of her But the fury herself speaks to me with tenderness and compassion ' $\mathrm{Oh}$ you poor man, what harsh decrees of fate have brought you here, where none have ever dared to tread before, I have seen no stranger yet?' I asked how far it was to Sorsele - 'That we know not' she answered, 'but you will not arrive before seven days hence in these conditions, my husband said" "Linné $1961,54)$

Carl von Linnaeus had begun the arduous journey on May 31st after high mass in Lycksele church He intended to get to Sorsele church village on the Vindel river (Lınné 1961,46) The sprıng floods and the wet bogs nevertheless forced him to turn back When the retreat began, he was in a Saamı tax district called Blåberg, in the name of Enwaldh Tomesson, whose wife was probably the "fury" described (Wiklund 1925, 68) 
Fig 1 Hoffman's portrait of Linnaeus from 1737 The cos tume of reindeer calf leather was probably from Torne lappmark In his right hand the Lappland traveller is holding a linnaea and in his left hand the drum of An ders Nilsson Pont

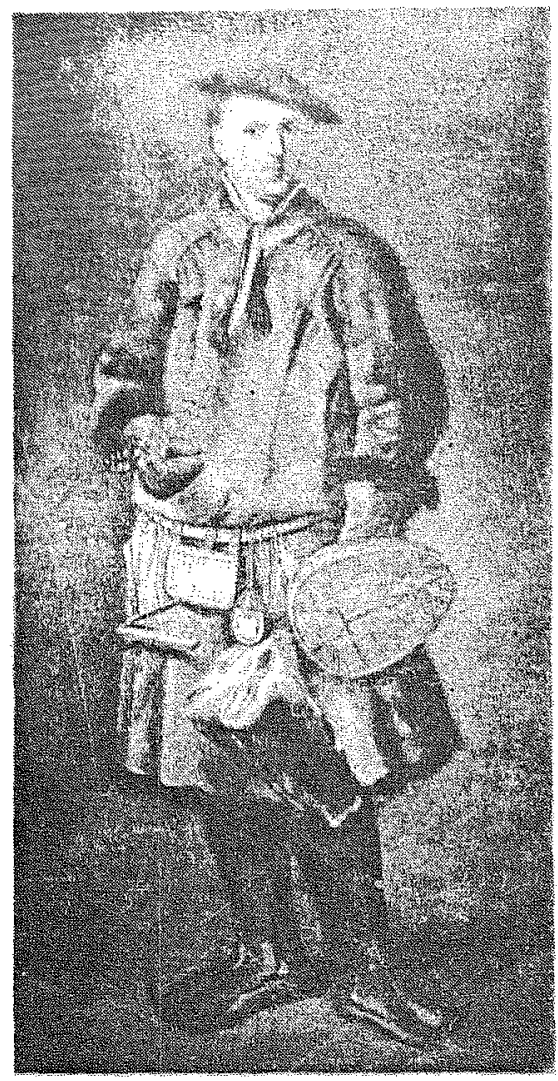

When Linnaeus made his journey to Holland in 1735, a Saamı drum was included in his baggage It also appears on the famous Linnaeus portrait by the Dutch master, Martin Hoffman The original owner of the drum was the Saaml, Anders Nilsson Pont of Granbyn "who lives close to Sorsele but never comes to church there " (cf Manker $1938,700)$ On the actual skin of the drum is written "Anders Nilsson i Graan" In this way Linnaeus received greetings from Lycksele lappmark, where he had never set foot!

During the rest of his iter lapponicum our great botanist was ex tremely sparing with information about the ancient Saami religion As far as the drum is concerned, it is mentioned by hearsay after his arrival on Norwegian territory $\mathrm{He}$ then writes: "In Norway I heard a strange story, about how someone used to take the drums away from the Lapps, together with certain images When he came across a drum, he used to order the Lapp to give it up, and the 
Lapp refused" (Lınné 1961, 111) It is not clear, however, whether Linnaeus himself had the chance to study a drum during his journey On the other hand, he made a couple of extracts from an unknown manuscript about the drum They appear as paragraphs 319-320 in his unpublished manuscripts and read as follows: "Lapp song, then, is beaten on the drum Hear the spruce wood ring and resound, rumble you good reindeer hide, runes here are rune bands ( $\left.{ }^{?}\right)$ and a true Lapplander's song - Spruce is the wooden case, reindeer hide the skin" It also says: "A ring, a snake or a frog is lard on the drum and he beats with a hammer until he stops at one animal or another, then he prophesies Rune drum Purchased" (Wiklund 1925, 89)

\section{Plantin and Bistock}

The most likely explanation is that Linnaeus got the drum from Georg Wallin the younger The latter, on the orders of his father Bishop Georg Wallin the elder, made a visit of inspection in 1715 As a result of this, he became very interested in the Saamı, not least in their old drums He apparently acquired the drum in question from his former teachıng colleague, Zacharias Plantin, pastor of Umeå Plantın belonged to an old Norrland clencal family His forefathers included Olaus Petrı Niurenıus, author of "Lappland or a relation of the northerly area, inhabited by the Lapps in the remotest parts of Scandia or Sweden" This was an important source, as we know, for Johannes Schefferus's Lapponıa, published in 1673

Plantın was born in Luleå in 1680 and was active as a teacher in Härnösand from 1711 In 1723 he became pastor of Lövånger and in 1730 was transferred to Umeå Here he died three years later His interest in the Lapland mission is evident, amongst other things, from the report he made to the diet of 1723 (see Haller 1896, $27 \mathrm{f}$ ) There is no clear evidence, on the other hand, that Plantin had any close personal contact with the Saamis or any detailed knowledge of their old religion (cf Reuterskiöld \& Wiklund 1912, $143 \mathrm{f}$ ) Nevertheless, there is a manuscript about the drum in his own hand This contains a description with interpretation of the Sorsele drum, and is dated Umeå, March 24th 1731 In addition, the Wallenstråle manuscript collection contains another interpretation of the drum's symbols, made by Arved Thuresson Bistock Both manuscripts were originally found in the posthumous papers of Georg Wallin the younger 


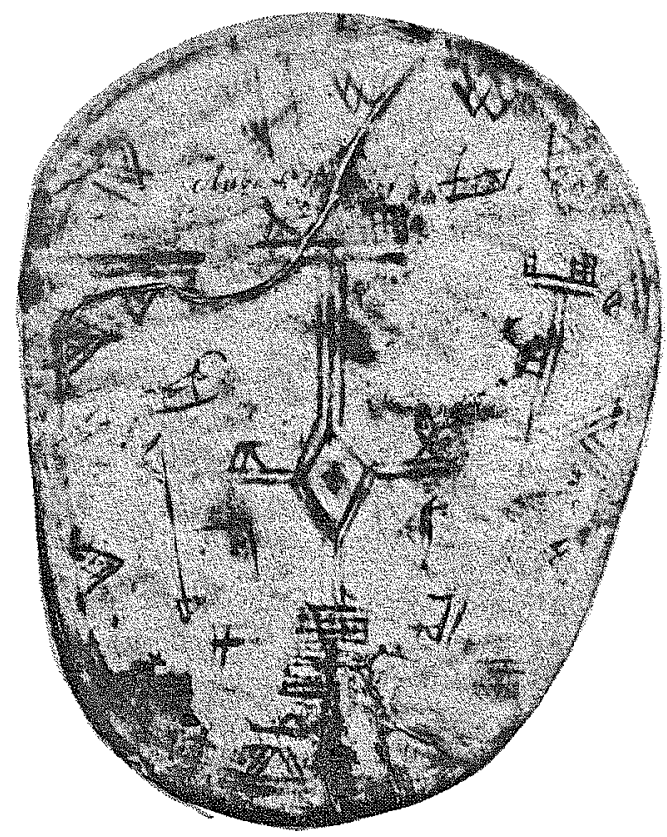

Fig 2 The Sorsele drum Pont's name appears up on the left hand side of the membrane

At the end of his account Plantin writes:

"The drum came from Lycksele Lappmark; but the explanation is by a schoolmaster from the Norwegian mission called Arved Thuresson, who for ten years lived in Norwegian Lappmark, and thus become an expert in these matters, in consequence of which one should not so lightly cast doubt on therr authority" (Reuterskiöld \& Wiklund 1912, 140 f)

From this alone, it appears that Plantın was strongly dependent on the account of Arved Thuresson Bistock The type of paper used in the two manuscripts is identical and might suggest that Bistock's undated manuscript was written during a visit to Plantın at the beginning of the 1730 's, "it can also be surmised that they met somewhere in the Lappmark" as K B Wiklund points out (Reuterskiöld \& Wiklund 1912, 144)

Who then is the Arved Thuresson referred to? There can be no doubt here that he is the same person as the catechist employed by Thomas von Westen for the Saamis of Rana and Vefsen This area also borders on Lycksele lappmark Judging from von Westen's letters, his colleague was born in Finland, with Finnish as his mother 
tongue, but in spite of this he matriculated as a Swedish student During the period of the Great Strife he seems to have fled from his homeland to Norway, where he wandered around for some time After a journey to Copenhagen, he visited von Westen in Trondheim "begging employment at the mission" He was allowed to stay with von Westen for a time, amongst other things to study Lappish under the guidance of Isak Olsen In the process, he apparently "learned so much Lappish that the Finns understood hım"

He completed his first year of service among the mountain Saamis of Vefsen During his journey of 1718 von Westen discovered "that among the mountain Lapps of Vefsen all was exceptionally well organized this year with Arved Bistock, who had visited, taught and found greater love and obedience in them than he had expected" It is also sald that the Swedes were to be thanked for some part of their healthy spiritual condition, for they spent the winter with their reindeer in Ume lappmark After this, Bistock had to go to Rana, but he was subsequently also to teach the Saarnıs of Vefsen and Bindalen before they moved to Sweden for the winter He was also to "help the Böyde Finns", that is the impoverished mountain Saamis who kept to the Norwegian side all the year round He therefore probably acquired his notions about pre Christian religious ideas through his activities among these Saamı groups It also seems likely that Bistock was acquainted with von Westen's comprehensive study in manuscript, "Missionsanstalter for Nordlandene", and that he had been influenced by the account of this "apostle of the Lapps"

Bistock could also confirm that the country's border did not consti tute any barrier to the practice of religion among the Saamis This experience is described by von Westen himself in his letter to the clergy of Jämtland on March 11th, 1723:

"for I have only too clear evidence that the Swedish Lapps and the Finns are still subject to the same heathendom as ours, and in many places among us the Swedish Finns and Lapps are far more versed in magic than ours, and are the masters and guides of our own Lapps and Finns" (Källskrifter 1910,4)

As far as Bistock's analysis of the signs on Linnaeus's drum is con cerned, one more point should be observed In von Westen's missionary methods the drum had a central place: thus Reuterskiöld writes that

"of von Westen's working methods, we soon find that what allowed him, once he had won the Lapps' confidence, to acquire such a thorough knowledge of 
their religious doctrines, was the fact that he made the drums the basis of his study We see how in every place the 'Rune drum', through some strange new figure, gives von Westen a further insight into the secrets of the Saamis We see clearly that, without this, we would hardly have obtained any knowledge of their religious ideas, however familiar he was otherwise to become with their habits and customs" (Källskrifter 1910, VIII)

Mebius therefore claims:

"This is probably the only completely reliable way of obtaining an idea of their drum pictures It is valuable from the point of view of source criticism that we have as clear a picture as possible of how von Westen acquired his knowledge of Saamı religion" (Mebuus 1968, 13)

On the other hand, Mebius urges caution when the historian of religion uses the drum figures as a source "Pictures without comment by the artist are fragile material, which can easily lead the interpreter on a wild goose chase" (Mebıus 1968, 3) Thıs writer nevertheless finds it unnecessary to "go so far as $\mathrm{J}$ de Vries, who regards the source value of the drums as relatively meaningless ('z1emlich bedeutungslos')" (Vries $1956,131)$ It should be noted, however, that this description refers primarily to the relevance of drum symbolism in the study of Germanıc religıon (see Lundmark 1982, 8) Bäckman also adopts a cautious attitude towards the drum's 1conography and its interpretation She writes: "Because of the uncertainty and constraint to which the Lapps were subjected, we also have reason to believe that a certain 'political calculation' may be observed in the picture gallery" She also assumes that "the symbols of the drum were rather vaguely experienced" by the ordinary man, and "only the noajdi understood the whole mystery of his own symbols" (Bäckman 1975, $41 \mathrm{f}$ )

We have reason to suppose that Bistock was traıned in von Westen's spirit and was careful to have the drums interpreted when he came across them (for Arved Thuresson Bistock's biography, see also Reuterskiöld \& Wiklund 1912, 141 ff, cf Källskrifter 1910, 19, where Carl Solander in his 1726 account mentıons Bistock as "vice Missıonarius" in Rana - According to Grape 1853, 51 Bistock married Anna Vacker, widow of the pastor of Silbojokk and Sorsele, Lars Rangius. Cf Svare 1970, $115 \mathrm{ff}$, see also Hammond 1787, $316 \mathrm{f}, 344,660 \mathrm{ff}$, $688,690,693)$ The idea is also supported by the introduction to the interpretation of Linnaeus's drum: "According to the account of the Norwegian Lapps I have written what is to be found on their magic drums " (Reuterskiöld \& Wiklund 1912, 136) These "studies" 
were decisive in the latter's analysis of the drum from Sorsele We can only regret that he did not have the opportunity to go through the drum's symbols with its owner, Anders Nilsson Pont The latter, however, died in 1723 From all the evidence, he still had the drum in his possession at that time

\section{Anders Nilsson Pont}

Anders Nilsson Pont, then, was from Granbyn The family name of Bonta is known later from Umbyn in Tärna The South Lappish baianta means one who is rich

Anders Nilsson is mentioned in two court records from Lycksele, one in connection with the ecclesiastical court held by the well known dean of Umeå, Nils Grubb Another Granby Saam,, Sjul Sjulsson, was reported for beginning to "play" on his magic drum, when the schoolboy Erik Gerano was about to pray Sjulsson confessed "sayıng that he had played in order to find out if he would be lucky with the animal trap he planned" Four other Saamis were denounced for the possession and use of drums The fourth of these was Anders Nilsson Pont According to the court record:

"Olof Pålsson of Gran witnessed that it was true and that he hımself had seen the drum in his home. But the sald Anders Nilsson Pont is not present at this moment" (Reuterskiöld \& Wiklund 1912, 130; cf Manker 1938, 700)

During the period January $12-16,1722$, a district assizes was also held in Lycksele, where it became evident that a number of Saamis in Rana and Vapsten had drums in therr possession and were using them The court's judgement begins as follows:

"The district assizes, on the basis of the above examination and the personal confession of the Lapps, can do no other than find that through the use of their drums or drumming to gather information on the whereabouts of lost reindeer, and otherwise predict whether their hunting expeditions would be successful, have thereby used superstition and signs etc and thus been liable to the penalty prescribed in his Majesty's revised Ordinance on Oaths and Swearıng of October 17, $1687 \& 9$, and inasmuch as the Royal Ordinance decrees that the penalty should be applied according to each person's age and understanding, and all of these Lapps are now come to a ripe age; but are nonetheless foolish in their Christianity" (Reuterskiöld \& Wiklund 1912, 130 f , cf Manker 1938, 701) 
Fig 3 The bottom of the bowl drum with its charac teristic handle

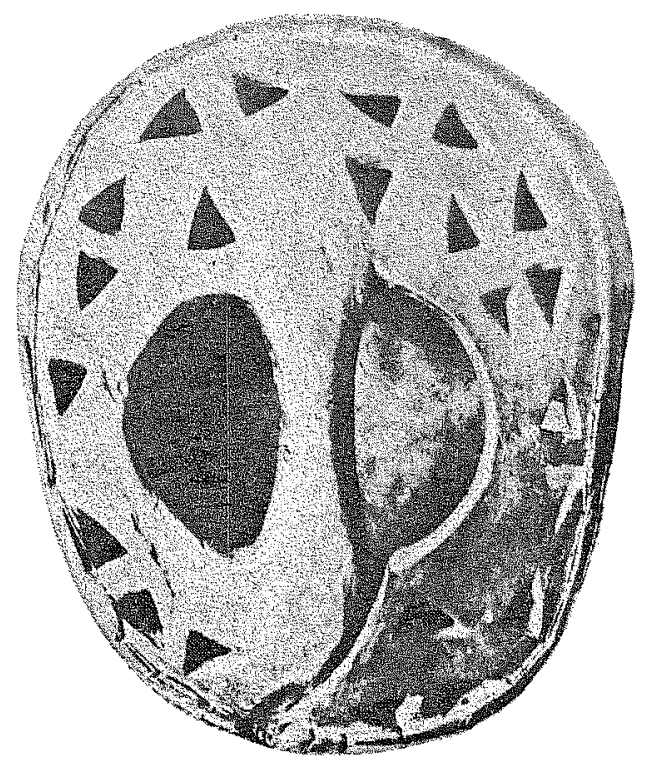

Abb 757. Trommel $\mathrm{Nr} 45$ Bodenseite 12.

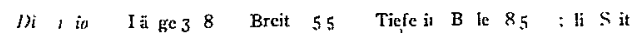

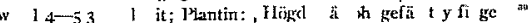

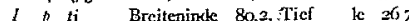

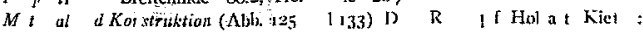

The Saamis in question were to hand over their drums by the following assizes at the latest, whilst the question of punishment was to be decided in the Court of Appeal Sentence was pronounced on November 28, 1723, and consisted of eight days imprisonment and one compulsory Sunday church attendance,

"and let them be solemnly forewarned to restrain hereafter from such ungodliness, if they wish to avoid a severer punishment; and they should also be made to give up their drums immediately, if this was not already done" (UUB N 348, n:o 49)

The sentence also became known on the Norwegian side and is mentioned in a letter from Thomas von Westen dated July 29, 1724 The "apostle of the Lapps" criticised the sentence and urged that enlightenment was more appropriate than secular punishment (Hammond $1787,522)$ Pont avorded serving the sentence by his decease It was probably after this that the drum was handed over to Pastor Olaus Graan in Lycksele 
Reuterskiold and Wiklund believe that Anders Nilsson was a forest Saami and that his drum therefore represents a more or less current type among the forest Saamu in the northern part of Lycksele lappmark (Reuterskiöld \& Wiklund 1912, 133; cf Wiklund 1930, 95) In this context they observed that Pont's home was at Sorsele near the church Graan or Granbyn was nevertheless a mountain Saami area Further more, the possibility cannot be excluded that Pont did not settle here until he was older In any case, it does not seem justified to limit this type of drum exclusively to the forest Saami area Nowadays, reindeer herding among the forest Saamis is practised no more within Sorsele and Stensele parıshes, while it is still being carried on in the neighbourıng parishes of Arvidsjaur, Arjeplog and Malå

\section{Symbol analysis}

In construction, Pont's gievrie is a so called bowl drum with an egglike oval shape It $1 \mathrm{~s}$ about $32 \mathrm{~cm}$ long by $25 \mathrm{~cm}$ across and made from clean pine, not spruceroot as Plantin claims in the course of his drum interpretation The skin is of reindeer hide Plantin writes:

"The cover on which the drawing is made, as with other drum skins, is probably of reindeer calf, particularly as it is farly thin" The colour is yellowish-grey to yellowish-brown and the skin is fastened by two plaited sinews The painting of the figures has been done, as was the custom, with alder-bark colourng Plantin does not seem to be aware of this method, as he writes: "The painting is red, doubtless of hurnan or other animal blood" (Reuterskiöld \& Wiklund 1912, 140; cf Lundmark 1983, 79)

The Sorsele type is defined by Manker as "Schalentrommel mit Bemalung von wesentlich Asseletypcharakter; Darstellung stark verennfacht und schematisch" (Manker 1938, 97) Of the different figures on the Linnaeus drum, it is in fact only the reindeer that are naturalis tically portrayed The spatial division largely corresponds to what is normal for drums in Åsele lappmark There is no explicit tripartite division, whilst the sign of the sun dominates in the middle with two horizontal and two vertical rays There is the possible suggestion of a horizontal bipartite division, since to the left there is a double line, with another similar one on the ray of the rising sun

Right from his very first contact with the Linnaeus drum, Reuterskiold maintaned that the pictures were mainly arranged as on the 


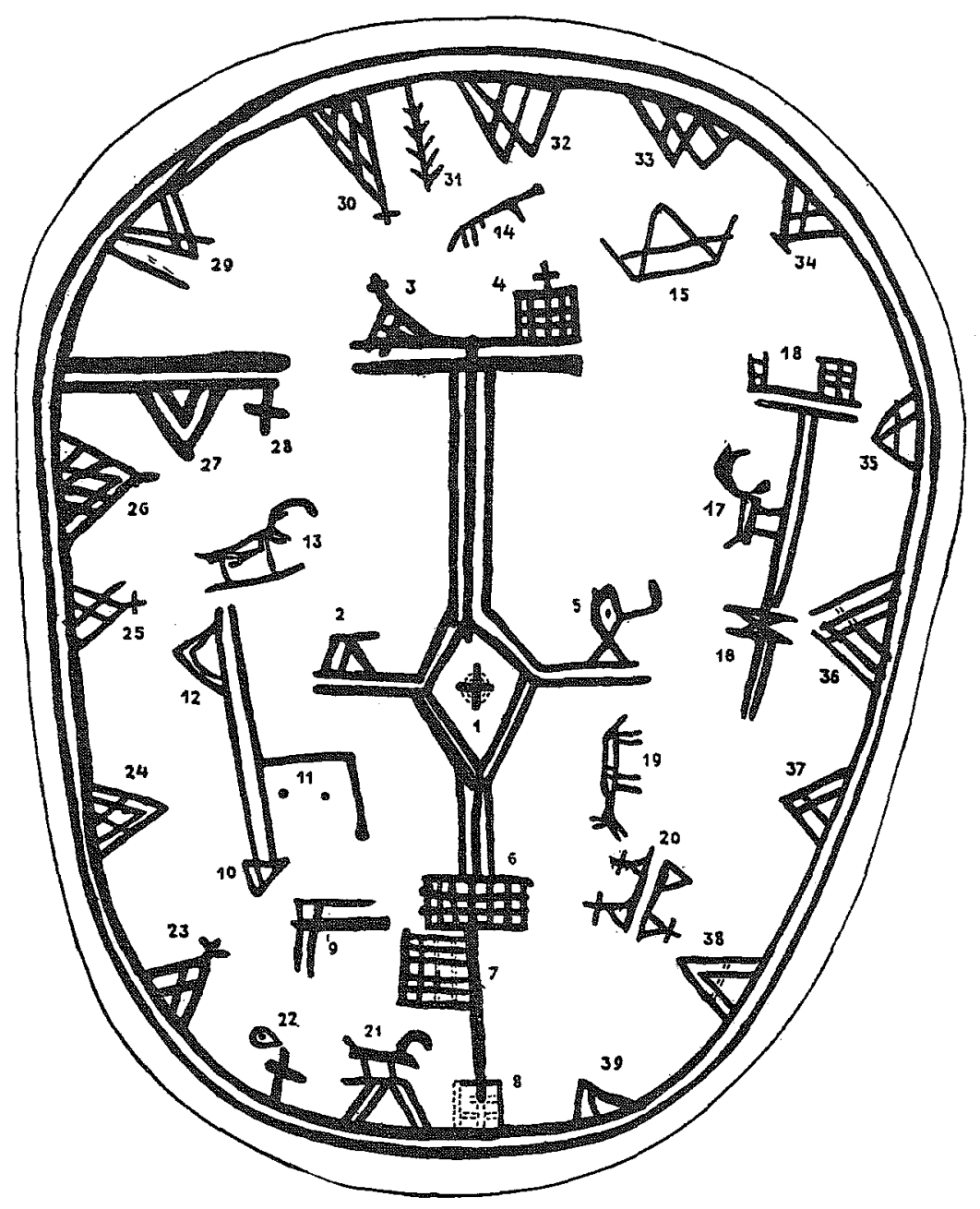

Fig. 4 A tracing of the symbols on the Sorsele drum with the numbering made by Ernst Manker and Harald Farth Ell

The animal world is represented by the reindeer bull (fig 13), the beaver (fig 14) and the wolf (fig 19) The boat symbol (fig. 15) is a reference to the small birch bark boats which used to be sacrificed at Christmas time There is a possible connection here with the lunar cult

Among the female deities one may note Rana niejte with the distaff (fig 29), "the goddess of the first greenery" together with Saraahka Juoksaahka and Oksaahka (figs 37-39), who were recponsible for man's creation and for the supervision of the newly born 
Åsele type, "but the body of the drum is of another type Furthermore, the figures of divinities are drawn in a schematıc, straightlined way, which does not occur on any other known drum" This author only finds "Biexolmai and Gissenolmal (the summer and winter weather gods) more or less individually worked out" (Reuterskiöld $1910,18)$ This is probably a reference to nos 5 and 2 in Manker's numbering The interpretation of fig 5 also largely corresponds to Manker's "Bieggolmai (Bieggagalles), der Wind" (Manker 1950, 364) In a despatch from Dean Henric Forbus to the King, dated March 29, 1727, the following comment is made on the Wind-man: "summer god, presiding over weather and wind, water and sea An offering is made to hım of a wooden shovel" (Källskrifter 1910, 33) In the latter's addenda and corrigenda from the same year, this remark is clarified: "Bieckolmai is made offerings of a wooden shovel or more precisely when an offering is made to him, a shovel is set up in his honour and left standing where 1t 1s" (Källskrifter 1910, 64) Hans Skanke provides the following characterisation of the "Wind-man" or Bjegsgalles: "the Wind god, who throws out weather and storms with his shovel, which they called Kolwo" (Källskrifter 1910, 100; cf IpS gåajvodh, to scoop) Among the Vapsten Saaml it was sald that

"Verro, the wind, shovels snow for the blizzard Regarding Verro, there was an amusing anecdote according to which he previously possessed a whole gaivo, or shovel, and then he shovelled snow so that it was impossible to live in the country, but the shovel fortunately broke, so he was left with only half a shovel, and then the country became habitable" (Pettersson 1979, 86; cf IpS vaejroe)

Linnaeus's drum has the outline of a shovel On several drums Biegkealmaj appears with two wind shovels Bistock's interpretation of this figure is as follows: "the east of the world where things are better" while Plantın writes: "the Eastern end of the World" In his interpretation, Bistock clearly refers to Biegke ålmaj's character of a "summer god" and the east as the summer cardinal point

Reuterskiöld's first interpretation of fig 2 as "the god of winter weather" is rejected by the writer in a later analysis The prefix Gissen or Jisen corresponds to jijsie in the sense of "hoar frost on the grass" Forbus writes: "Gissen Olmal, a god presiding over weather, snow and ice Offerings are made to him so that the ice will not harm the reindeer, and so that the snowstorms will stop" (Källskrifter 1910, 33; cf Sidenıus's account in Källskrifter 1910, 57) Manker's interpretation 1s: "Horagalles, das Gewitter" (Manker 1950, 
362) Corresponding to fig 5 Bistock suggests: "the Western end of the world, where he is sent by the sorcerer so that he will not return to his people agaın" while Plantin summarses: "the Western end of the World" (Reuterskiöld \& Wiklund 1912, 137) It is with reference to Friis's second drum and Forbus's drum that Reuterskiold and Wiklund introduce Hora-galles into the discussion of this figure (Reuterskiold \& Wiklund 1912, 151)

In this context we should also inention Arvid Thuresson's interpre tation of figs 10-11, 1.e "the church of the evil dead one" and "the wild path on which he sends sorcerers so that they will not find their right way home again" (Reuterskiöld \& Wiklund 1912, 138) Manker interprets figs 10-12 in a single context: "Savvo (?) oder passe, eın heiliges Gebıet, mıt Koten, den Wohnstätten der Unterırdischen (10 und 12) sowle ein von dort führender Irrweg ( ${ }^{11) " ~(M a n k e r ~ 1950, ~}$ 365) Bistock never theless gives no 12 as a "Christian church" and the double line unnumbered by Manker as "the way between the church of the dead and the church of the living" (Reuterskiöld \& Wiklund 1912, 138) In the complex of figures 16-18 the double line is also ignored by Manker, whilst Bistock characterızes it as "the path to Christianıty" The break below the line he interprets as "a sickbed, where the person will lie sick who has acted against the soothsayer" (Reuterskiöld \& Wiklund 1912, 138) No 16 is interpreted by Manker, on the other hand, as "Salvo mit Lager" and no 17 as "Rentieren (Manker 1950, 367) Bistock claims that the reindeer figure reproduces "áppe godo" $1 \mathrm{e} a$ a as "the wild reindeer of the sea" or "the wild reindeer of the great bog", which would also be connected with the nåjd (Reuterskiöld \& Wiklund $1912,137 \mathrm{f}$ ). Manker would like to interpret no 18 as "graves", whilst for Bistock 1t stands as "the greatest world" (Reuterskiöld \& Wiklund 1912, 137 f.) Here, Manker's predecessor finds "the place provided on many southern drums for the "ristabalgis", 1 e the Christian path (Reuterskiöld \& Wiklund 1912, 154)

The examples already mentioned show that the pattern of inter pretation for the Åsele drums has been decisıve for Manker in his reading of the signs on Anders Nilsson Pont's drum from Sorsele Analogies with the drum material from suuth of the Umeå river have prevented Arved Thuresson Bistock's analysis from being applicable to any great extent The latter's presumed familiarity with Rana and Sorsele drums for geographical reasons has not appreciably influenced Manker's suggestions for interpretation As an additional example we may mention fig 33 IIere Bistock finds "Thor who reigns" (Reuter 
skiöld \& Wiklund 1912, 139) In his introduction the latter also mentions "raıdeie" (lpS raegrie) i e "the thunderer" (Reuterskiöld \& Wiklund 1912, 136) As previously suggested, fig 2 is the thunder god in Manker's opınıon, whilst fig 33 is interpreted as: "Radienakka or Radienattje" (Manker 1950, 371)

(With reference to the sun symbol fig 1 , see the section entitled "the Sun on the Drum" in Lundmark 1982, $39 \mathrm{ff}$ )

By all accounts, then, Pont was allowed to keep the drum until his death, but was not able to carry it with him to the grave Where he departed this life, we cannot ascertain If the drum was a summary of his beliefs, he was expected in one the three underworlds included in figs 6-8 Bistock's interpretation here 1s: (6) "nearest hell, Or as the Lapps say Jame1 aımo, (7) middle hell, Or siappes-aimo, (8) great hell or rotta land as the Lapps call it and which is the lowest" (Reuterskiöld \& Wiklund 1912, 138) In this case, the interpretation is accepted by Manker The meaning of Tjeephes aajmoe becomes more or less "the black world"

When Bäckman discusses Saamı notions of the realm of he dead, she sees one possibility that "life after death was differentrated, since the idea that different kinds of death result in different destinations after death, was found elsewhere among the beliefs of the Finnish peoples" She also believes it probable that Ruto's kingdom is autochthonous on Saami territory, which does not exclude the possibility that Catholic preaching could have spread knowledge of a hell with its horrors, which was then applied to Ruto-aajmoe (Bäckman 1975, 109)

Perhaps Pont looked forward to existence in another world, like that described by Jessen, where he would be able to "carry on the same practices they had been used to, that is to divine, to hunt, to lie with women, eat, drink, dance, smoke and become merry with brandy" (Jessen 1767, 66) The latter bases his ideas on Hans Skanke's Epitomes Historiae Missionis Lapponicae Cf Manker 1961, 17 "A synthesis of jabmearmo and salvo motifs are conspicuous here")

The learned Linnaeus, to my knowledge, never tried personally to interpret the signs on the drum, any more than he made use of it to solve the mysteries of nature Although both the hammer of reindeer horn and the three pointers in the form of brass rings were already missing at the time of the journey to Holland, he nevertheless held a "seance" in Hamburg drumming with two stıcks He later gave the drum to one of his disciples, Carl Petter Thunberg, before it went abroad once again, to the French National Museum in Paris From there it was returned to Sweden and the National Historical Museum 
in exchange for a collection of Saam objects Since 1933, the socalled Linnaeus drum has been deposited at the Linnaeus museum in Uppsala (cf Lundmark 1983, $77 \mathrm{ff}$ ) But on the skin of the drum one can make out the name of the person who needed it right until the end: Anders Nilsson Pont from Granbyn at Sorsele on the beautiful Vindel river!

\section{Bibliography}

\section{Abbreviations}

lpN North Lappish

lpS South Lappish

\section{UNPUBLISHED SOURCES AND LITERATURE}

Uppsala

UUB Uppsala Unıversitetsbibliotek

[According to the Manuscript Catalogue]

N 348, n:o 49

PUBLISHED SOURCES AND LITERATURE

Bäckman, L 1975 Sáiva (Stockholm Studies in Comparatıve Religıon 13) Stockholm

Grape, I 1853 Minne af presterskapet ^ Lappmarksförsamlingarne ınom Hernösands stift Umeå

Haller, E 1896 Svenska kyrkans mission ` Lappmarken under frihetstiden Stockholm

Hammond, H 1787 Den nordiske Missions Historıe ^ Nordlandene, Fin marken og Trundhrems amt [ ] Kiøbenhavn

Jessen, E J 1767 Afhandling om de Norske Finners og Lappers Hedenske Religion Kiøbenhavn

Källskrıfter till lapparnas mytologi 1910 [Ed by] E Reuterskiöld (Bidrag till vår odlings häfder 10 ) Stockholm

Linné, C von 1961 Carl von Lannés Lappländska resa 2 uppl Stockholm

Lundmark, B 1982 Baeı vi Mánno Nástit (Acta Bothniensıa occidentalis 5) Umeå

- 1983 Linnes samiska trumma Svenska Lınnésällskapets årsskrıft 198283 Uppsala

Manker, E 1938 Die lappısche Zaubertrommel 1 (Acta Lapponica 1 ) Stockholm

- 1950 Die lappische Zaubertrommel 2 (Acta Lapponica 6) Stockholm

- 1961 Lappmarksgravar (Acta Lapponica 17 ) Uppsala

Mebıus, H 1968 Värrō (Skrifter utgivna av Religıonshıstoriska instıtutıonen I Uppsala, Hum fak , 5 ) Uppsala 
Pettersson, O P 1979 Kristoffer Sjulssons minnen [Ed by] L Bäckman \& R Kjellström (Acta Lapponica 20) Stockholm

Reuterskiöld, E 1910 Linnés lappska trolltrumma En Linnéreliks öde Fa taburen Stockholm

Reuterskiöld, E \& Wiklund, K B 1912 Linnés lappska trolltrumma 2 Fataburen Stockholm

Sidenıus, L 1910 Relation Källskrifter till lapparnas mytologı 1910 [Ed by] E Reuterskiöld (Bidrag till vår odlings häfder 10 ) Stockholm

Svare, R 1970 Skulestellet 1 Vefsn frem til 1900 Vefsn bygdebok Saerbind 1 Mosjøen

Wiklund, K B 1925 Linné och lapparna Svenska Lınnésällskapets årsskrift 1925 Uppsala

- 1930 Olof Rudbeck d. ä och lapptrummorna Rudbecksstudier Uppsala Vries, J de 1956. Altgermanısche Religionsgeschichte 1 Berlin 